\title{
Features of Non-Tariff Regulation of Construction Products Market in Ukraine
}

\author{
Oleksandra Marusheva, Yurii Prav
}

\begin{abstract}
The article deals with the issue of state regulation over the construction products industry. Analysis resulted in the identification of two main forms of regulation: tariff and non-tariff regulation. Global practices show the effectiveness of non-tariff regulation in the construction industry. Being a WTO member, Ukraine has to implement the legal framework of non-tariff regulation, in regards to those aspects contributing to compliance with the rating and standards of the European Union to ensure the quality of products. The main objective of non-tariff market regulation is to ensure the quality of finished products, environmental protection, health and safety of life. The national system of regulation, including technical rate-setting of the construction products manufacturing must comply with the international documents ratified by Ukraine. The article analyzes the domestic legal framework and proposes an algorithm for designing a national system of non-tariff regulation in accordance with international rules and standards.
\end{abstract}

Keywords: Public Administration. Public Administration Mechanisms. Construction. Construction Products Market. Non-Tariff Regulation

\section{INTRODUCTION}

Nowadays, the national economy is developing in an open market and competition not only between economic actors at the national level, but also outside the country, entering the markets of the European Union and world-wide markets for goods and services. Under transformation processes of the national economic system, one of important development aspects is the identification of effective mechanisms for regulating production relations and social processes in the system of public, regional and local authorities, the private sector and the public. An important task is improving legal support for the processes of implementing market regulation mechanisms. Non-tariff regulation is one of the priority areas of regulatory policy.

The international practice shows that the global trend in trade of goods and services is reducing barriers at the global economic level. Minimization of restrictions for economic activity contributes to the development of foreign trade and opens new prospects for further development of economic entities. Liberalization of economic activity is a priority of the state policy in the leading economically developed countries. The world economy is developing in conditions of minimizing customs barriers, market openness and fair competition at the global economic level, which contributes

Revised Manuscript Received on November 15, 2019

* Correspondence Author

Oleksandra Marusheva, Department of Public Administration, Interregional Academy of Personnel Management, bldg. 23, 2 Frometivska St., Kyiv, 03039, Ukraine

Yurii Prav, Department of Public Administration, Interregional Academy of Personnel Management, bldg. 23, 2 Frometivska St., Kyiv, 03039, Ukraine to an increase in foreign trade turnover. The specific objectives of state economic and trade policy determine the mechanisms of state regulation for ensuring the development of trade activities and determining the boundaries of regulatory impact for the economy revival. In particular, a system of contractual relations (bilateral and multilateral treaties), methods of tariff regulation, methods of non-tariff regulation can be determined among such mechanisms of the state regulatory policy on ensuring the development of trade and economic activity. The international experience shows that the methods of non-tariff regulation are more effective and relevant in modern economic conditions. Therefore, it is reasonable to consider methods of non-tariff regulation of trade and economic activity.

One of the urgent tasks for the domestic economy is development of the construction industry as a country's economy multiplier. The construction industry can become the basis for further development of related economy sectors; it determines the level and the potential of infrastructure development, creation of comfortable living conditions for the population. It is important to provide the industry with the necessary resources for the development of construction. Thus, the issue regarding development of the construction products market as a basis for forming sustainable development of the construction industry, non-tariff regulation of construction products industry are relevant issues.

Despite the relevance of non-tariff regulation in construction products industry, research on this issue is currently insufficient. The analysis of non-tariff economy regulation as a whole in the domestic and worldwide markets was carried out in the works of a number of scientists $(a, b$ Nepomnyashchyy 2017; Romanenko 2016; Troshkina2010). Having accumulated the authors' experience, the article investigates the subject of non-tariff regulation for the construction products industry.

\section{OBJECTIVES}

Development and improvement of the mechanisms of non-tariff market regulation of construction products in Ukraine based on the best practices.

According to the set purpose, a number of tasks aimed at its achieving it are defined, namely: identifying tendencies in the market of construction products; analyzing mechanisms of non-tariff regulation for the construction products market; developing certain aspects of technical regulation as a non-tariff market regulation mechanism for the construction products; analyzing the existing system of non-tariff market regulation for construction products in Ukraine; researching and making use of experience of the European Union on non-tariff regulation of the construction products market; searching for ways to 
improve the system of non-tariff regulation of the construction products market in Ukraine by means of technical regulation.

\section{MATERIAL AND METHODS}

The research uses scientific methods, namely: formal logic, empirical research, economic and statistical method, analysis and synthesis, modeling and analogy.

The official database of the study is official statistics and current legislation, obtained from the official websites of the State Statistics Service of Ukraine and the Verkhovna Rada of Ukraine, as well as open access information from publications and personal experience of research authors.

\section{RESULTS}

There are trends in the construction products market in Ukraine that correspond to the construction market tendencies, which were changing throughout the entire period of independence from the critical minimum indicators to growth and stabilization. Starting from 2000 on, Ukraine witnessed a revival of construction activities. Construction companies increased the volume of construction operations quite rapidly. Consequently, the construction needs were met with the necessary resources and materials. The market of construction products was actively developing, production volume was increasing, particularly with the help of applying innovative technologies. The 2008 economic crisis slowed down the growth of the construction market, the production volume of construction products reduced respectively. The market instability and currency fluctuations had a negative impact on the market of construction products. Economic activity revived only in 2010-2011, when the country started to actively prepare for EURO 2012 European Football Championship which included the construction of sports, tourism and transport infrastructure. In general, there have been positive trends in the development of the construction industry since 2010 (Official site).

In 2014, there was a steep downfall of the construction market, which is associated with the beginning of hostilities, a fall in the national currency, political and economic instability in the country. But since 2015 we can see some growth in the volume of construction operations (Official site). Construction of engineering buildings and structures prevails in a structure of construction operations, as well as non-residential real estate.

In 2011, index of manufactured products in the construction products market increased by 20 per cent compared to the previous year. In 2017, this figure was 26.3 per cent (Propertytimes. Analytics). Trends in growth are also observed in the market of construction products in 2018-2019.

The research on the development of the construction products market gains special importance, taking into consideration their usage in renovation of homes, as well as social, commercial and engineering facilities in Donetsk and Luhansk regions, which suffered considerable damage due to active hostilities.

In recent years, the structure and indices of the construction market of Ukraine have changed, in particular, the share of imports of construction materials has decreased due to currency fluctuations and depreciation of the national

currency. In order to keep the prices on finished construction products within the purchasing demand of the population, construction companies increased the volume of purchases from the national manufacturer. This provides additional opportunities for the development of the construction products market in Ukraine. Thus, today the average percentage of domestic construction products used by developers for manufacturing construction products is $75-80$ per cent (Property times. Analytics). General trends in the ratio of exports and imports of construction products (based on official data of the State Statistics Service of Ukraine) are shown in Fig. 1.

However, currency fluctuations and inflationary processes affect the domestic market of construction products. Over the past year, the price growth rates for the main construction products of the national manufacturer were $30-40$ per cent (Official site). This was the result of postponing the price increase. Due to a significant decline in construction operations and currency fluctuations in 2014, which led to a significant depreciation of the national currency, manufacturers of construction products reduced the rate of price growth to prevent a catastrophic decline in consumption. Having lost a part of the profit, companies dealing with production of construction materials raised their prices in 2016-2017, when the volume of construction operations was resumed and the demand for construction materials and products began to grow. This explains the price growth rate for construction products, which is higher than the average inflation rate. Now the market has stabilized and has the prerequisites for active development.

Mechanisms of non-tariff regulation are generally accepted in the international business practice and are one of the most effective mechanisms for implementing state regulatory policy. Presently there is a sharp question in Ukraine regarding the legal support for mechanisms of non-tariff regulation of construction products. After all, in the conditions of price stabilization in construction and construction products market, the issues of non-tariff regulation in regards to ensuring the quality of products, their compliance with rules and standards come to the fore.

The system of non-tariff regulation can be defined as "a set of tools and measures aimed at harmonizing the processes of import and export of goods in order to ensure the normal functioning of foreign trade relations" (a, Romanenko, Chaplai 2016).

Researchers (Alekseev 2003; a, Romanenko, Chaplai 2016; Nepomnyashchyy et al. 2018) define different approaches to non-tariff regulation, among which are regulation of foreign trade operations (quota arrangement, license activity, trade restrictions) and non-tariff restrictions (administrative, environmental, health). Regulation of foreign trade operations is performed due to the application of a clear and transparent system of legal support aimed at streamlining the processes of foreign trade policy of the state.

Non-tariff restrictions are defined through a system of international treaties and are aimed not only at the classical implementation of non-tariff regulation, but also as the implementation of import substitution policy by limiting the supply of foreign producers in national markets. 
Non-tariff regulation instruments can be defined as a system of measures aimed at causing regulatory impact on the national and global trading systems through a set of regulatory framework and contractual regulation (b, Romanenko, Chaplai 2016).

The principle regulatory document on non-tariff regulation in world trade is the General Agreement on Tariffs and Trade (GATT), signed on October 30, 1947 (General Agreement). The document defines that relations in the field of trade and economic endeavour should be conducted with a view to raising standards of living, ensuring full employment and a large and steadily growing volume of real income and effective demand, developing the full use of the resources of the world and expanding the manufacturing and exchange of goods. Contributing to these objectives takes places by entering into reciprocal and mutually advantageous arrangements directed to the substantial reduction of tariffs and other barriers to trade and to the elimination of discriminatory treatment in international commerce (General Agreement).

The implementation of the General Agreement on Tariffs and Trade has led to creation of the World Trade Organization (WTO), which exercises regulatory influence on world trade to achieve the goals and objectives of the organization. The basis of the world trade order is the package of Agreements of the Uruguay round of multilateral trade negotiations, shaped during 1986-1994. These documents have become the legal framework of the World Trade Organization. WTO regulates more than 90 per cent of all legal relations in the field of world trade, and therefore forms international trade policy in accordance with the trends in the development of the world economic system.

Ukraine has joined the WTO and ratified legal documents regulating relations in the world financial and economic markets. Accordingly, work was carried out to transform the domestic legislation and bring it in line with the documents and requirements of the World Trade Organization.

To sign the Protocol on Ukraine's accession to the WTO, almost 50 bills were adopted in regards to protection of intellectual property rights, customs legislation, fiscal policy, regulation of agricultural development in Ukraine and others.

The economic benefits for Ukraine's accession to the World Trade Organization are as follows (Program of measures, 2002): improving access conditions for Ukrainian manufacturers and exporters to major international markets; increasing foreign investments in the state economy; liberalizing the trade regime between Ukraine and the EU, beginning negotiations on Free Trade Agreement between Ukraine and the EU; reducing tariff and non-tariff restrictions on exports of Ukrainian goods to the EU; obtaining the possibility to protect national manufacturers in anti-dumping, special investigations under the WTO trade dispute settlement procedure; preventing trade and economic isolation of Ukraine from the states of Central and Western Europe, as well as from the states of Eastern Europe and the Baltic region; creating an effective system of protection for national goods producers from unfair imports.

\section{DISCUSSION}

The global practice determines the mechanisms of ensuring regulatory activity in the sphere of trade operations, one of the most effective of which is non-tariff regulation.

Having joined the World Trade Organization, Ukraine determined the priority of the European legislative system in establishing trade relations in various sectors of economic activity. In addition, European partners have prioritized the protection of Ukrainian producers in the world economic markets. Thus, the domestic legal system needs to be transformed in accordance with the European trade legislation in order to protect its own producers and the transition to open competitive markets. This increases the relevance of introducing mechanisms of non-tariff regulation for various economy sectors, particularly the construction industry.

The World Trade Organization provides for non-tariff regulation, the legal basis of which is laid down in the Code of Standards of Technical Barriers to Trade Agreement (General Agreement). These documents define features of market regulation which are based on factors of sustainability, standardization and certification, safety of the use, quality of production, special characteristics of goods and so forth. On the basis of the regulatory support laid down in this Agreement, technical regulations, standards, sanitary rules, standardization procedures, evaluation, licensing of goods, individual production processes or production as a whole are developed and put into practice.

Under the Technical Barriers to Trade Agreement, WTO member countries are required to implement generally accepted standards in their national markets and develop their own standards in accordance with the recommendations of the Agreement. The main purpose of implementing these standards is to ensure sustainable development of society, environmental safety, social security, protection of human health and life. The technical regulation covers the import and export of goods of WTO member countries. International standards are the basis for the formation of national standards, thus, they ensure compliance with the quality of goods both in the world and in the national markets. Special geographical or climatic conditions that make adjustments to technical regulations and standardization of goods may be an exception. The state forms special institutions, develops rules of procedure, defines the rights and obligations under international legislative acts dealing with the processes of conformity assessment of goods to technical regulations and can provide recommendations for amendments to the existing technical regulation according to specific characteristics, except otherwise provided by international rules and standards agreed with the WTO. The World Trade Organization introduces unification of assessment procedure for product compliance with technical regulations in all member countries in order to ensure that certificates issued in each country have the same legal force. However, due to the differences in quality control assurance in various countries, a number of WTO member countries require similar conformity assessment procedures with technical regulations to be passed in the country of destination.

Having joined the World Trade Organization, Ukraine ratified the agreements defining mechanisms of non-tariff market regulation of goods, particularly, in the field of construction product manufacturing. However, the legal basis for implementing non-tariff regulation mechanisms in Ukraine is imperfect and requires further development. 
The Procedure of Implementing Trading Activities and Trading Service Rules on Consumer Goods Market, approved by the Resolution of the Cabinet of Ministers of Ukraine of June 15, 2006 № 833 (The Procedure) is basic as of today, the main purpose of which is to "define the general terms of trading activity by actors of wholesale, retail trade, restaurants, the basic requirements to retail and restaurant chains, trade consumer service (buyers) who purchase goods from enterprises, institutions and organizations regardless of their legal status and forms of incorporation, sole proprietorships and foreign legal entities involved in entrepreneurial activities in Ukraine".

The specifics of construction operations and non-tariff regulation mechanisms in the industry are partially incorporated in the following legislative acts: Law of Ukraine "On Regulation of City Planning Activity";Law of Ukraine "On Construction Regulations";Law of Ukraine "On the Principles of Town Planning";Law of Ukraine "On Architectural Activity";Law of Ukraine "On Technical Regulations and Conformity Assessment";Law of Ukraine "On Standardization";Resolution of the Cabinet of Ministers of Ukraine of 20.12.2006 № 1764 "On Approval of Technical Regulations of Construction Products, Buildings and Structures".

The law on providing construction products to the market could be a leading regulatory act on non-tariff regulation in Ukraine, which should be developed to implement provisions of Regulation (EU) No. 305/2011 of the European Parliament and of the Council.

Such Law should define the legal and organizational basis for the introduction or provision of construction products to the market by establishing rules for expressing their indicators related to the essential characteristics of these products, and the application of the technical regulations conformity mark. The background for forming a system of non-tariff regulation in Ukraine should be the documents as follows: the finding on technical assessment; harmonized European standard; the European assessment document; procedural technical specifications.

The sequence of non-tariff regulation of construction product manufacturing by means of technical regulation is presented in Fig. 2.

Thus, formation of a non-tariff regulation system can be based on arranging the regulatory impact of the relevant technical commission, which performs its work based on the harmonized European standards and the European assessment documents, which is the basis for the national standard according to the technical regulations of building materials.

In general, the Law should provide for the following stages of implementing the system of non-tariff regulation in the construction products industry: introducing technical legalization of construction products, which are not subject to the requirements of existing national standards; applying the principle of related regulation in the technical legalization of construction products; introducing market surveillance in the market of construction products; developing mechanisms of non-tariff regulation of construction products market by means of public administration; adjusting the current laws of Ukraine in the adoption of technical regulation of construction products.

\section{CONCLUSIONS}

The research has analyzed the issue of non-tariff construction industry regulation in regards to construction products. It is determined that due to the growth of construction operations, which comes against the background of the national currency depreciation, the demand for national construction products has increased, which opens up new prospects for the industry development. Since Ukraine is a WTO member, it implements mechanisms of non-tariff regulation of trade activities through the introduction of international rules and standards. The article proposes a scheme of implementation algorithm for a system of non-tariff regulation for the construction products industry, and identifies promising activities for developing elements of non-tariff regulation of the construction operations industry.

\section{VII.LIMITATIONS}

Basic requirements for structures are determined by the technical regulation and contain safety compliance parameters. Thus, basic requirements for the structures are main identified risks realized throughout the facility's lifecycle. Construction product standards and other technical specifications determine the essential features of the construction products in relation to basic requirements for structures. In other words, these are such features of a structure's (product's) component, which directly affect the risk degree while the final product of construction - structure is being operated. Boundary indices, levels and classes are determined for such essential features correspondingly to their boundary values.

In addition, a wide range of products used in construction are not characterized by indices that influence basic requirements for structures. Such products are not covered by technical regulation in construction and are not reviewed in this research. Non-tariff regulation of such products market is carried out on the basis of other factors economic, political, social, etc.

\section{RECOMMENDATIONS}

On the basis of the research performed, one can recommend the following promising measures to develop elements of the non-tariff regulation in the construction manufacturing sector: establishing the basic requirements for facilities throughout their life cycle and procedures of construction product technical testing for their placement on the market, as well as entities involved in the procedures of technical testing and declaration in construction; establishing mechanisms for determining the essential characteristics of technical indicators of construction products with respect to the basic requirements for structures, requirements for regulatory specifications, which are a national standard or technical approval; defining obligations of business entities (manufacturers, importers, authorized representatives), placing construction products on the market.

\section{REFERENCES}

1. Alekseev Sergey 2003.Regulationoftheuseofnon-tariffmeasuresinthe EU law. Ph. D Thesis, Unpublished: Moscow: MGIMO University. 
2. General Agreement on Tariffs and Trade, 15 April 1994. From <https://zakon.rada.gov.ua/laws/show/995_264> (Retried on 18 April 2019).

3. Nepomnyashchyy OM 2017. Problems and prospects of international investment projects implementation in Ukraine illustrated by international technical assistance projects (programs). Scientific Bulletin of Polissia. 1: 134-139.

4. Nepomnyashchyy OM 2017. Institutional and functional component of ensuring the investment project implementation in Ukraine. Scientific Bulletin of Polissia. 2: 90-96. DOI: 10.25140/2410-9576-2017-1-2(10)-90-96

5. Nepomnyashchyy OM, Medvedchuk OV, Lahunova IA 2018. Foreign experience in the regulation of construction activities. In: The Development of Public Administration System in Ukraine. Kharkiv: NAPA Publishing House, Issue 3 (62). pp. 188-196.

6. Official site of the State Statistics Service of Ukraine. From <http://www.ukrstat.gov.ua> (Retried on 18 April 2019).

7. Program of measures for the completion of Ukraine's accession to theWorld Trade Organization. Decree of the President of Ukraine of 5 $\begin{array}{llll}\text { February } 2002 & \text { No. 104/2002 } & \text { From }\end{array}$ <https://zakon.rada.gov.ua/laws/show/104/2002?lang=uk> (Retried on 06 May 2019).

8. Property times. Analytics. From <https://propertytimes.com.ua > (Retried on10 June 2019).

9. Romanenko YO 2016. Internet as a means of communication and its influence on public policy formation. Actual Problems of Economy, 175: 429-434.

10. Romanenko YO 2016. Place and role of communication in public policy. Actual Problems of Economy, 176: 25-31.

11. Romanenko YO, Chaplai IV 2016. The system of marketing communications in the mechanisms of public administration. Actual Problems of Economy, 4: 69-78.

12. Romanenko YO, Chaplai IV 2016 . The process of formation and directions of implementation of the marketing mechanism in the system of public administration. Actual Problems of Economy, 6: 102-109.

13. Troshkina Tatyana 2010. Non-tariff measures in the system of international trade public regulation: by developed countries examples. Ph. D Thesis, Unpublished: Moscow: Primakov National Research Institute of World Economy and International Relations, Russian Academy of Sciences.

14. The Procedure of introducing trading activity and rules of trade service in the market of consumer goods. Resolution of the Cabinet of Ministers of Ukraine of 15 June 2006 No. 833. From <https://zakon.rada.gov.ua/laws/show/833-2006-\%D0\%BF>(Retried on 06 May 2019). 